\title{
KARAKTERISTIK DADIH PROBIOTIK MENGGUNAKAN KOMBINASI LACTOBACILLUS CASEI, LACTOBACILLUS PLANTARUM, DAN BIFIDOBACTERIUM LONGUM SELAMA PENYIMPANAN
}

\author{
(Characteristics of Probiotic Dadih using Lactobacillus casei, Lactobacillus plantarum, and \\ Bifidobacterium longum During Storage) \\ Sri Usmiati $1^{*}$ dan Juniawati ${ }^{1}$

\begin{abstract}
${ }^{1}$ Balai Besar Penelitian dan Pengembangan Pascapanen Pertanian Jl. Tentara Pelajar No. 12 Kampus Penelitian Cimanggu-Bogor

* Alamat korespondensi: Balai Besar Penelitian dan Pengembangan Pascapanen Pertanian Jl. Tentara Pelajar No. 12 Kampus Penelitian Cimanggu-Bogor.
\end{abstract}

\begin{abstract}
Some test results hedonic by ordinary people who consume the dadih in West Sumatra in 2009 on dadih made from cow's milk using Lactobacillus casei culture couldn't be accepted because it was still too acidic than dadih from buffalo milk. One solution to reduce the sour taste is to combine the bacterial culture $L$. casei with other lactic acid bacteria that produce flavor relatively low acidity. The study aimed to determine the characteristics of probiotic dadih using a combination starter $L$. casei, L. plantarum and B. longum during storage at room temperature (ambient) and cold temperature. The study was designed using randomized block design with $6 \times 3$ factorial patterns of three groups as replication. Treatment $A$ (combination of probiotic bacteria) that $L$. casei (A1), B. longum (A2), L. plantarum (A3), L. casei: L. plantarum 1:5 (A4), L. casei: B. longum 1:5 (A5) and L. casei: L. plantarum: $B$. longum 1:4:1 (A6), and factor $B$ (storage conditions), namely: (B1) room temperature $\left(27^{\circ} \mathrm{C}\right)$, and $(B 2)$ cold temperature $\left(4-10^{\circ} \mathrm{C}\right)$. The results showed that viability and the total lactic acid bacteria in all formulas of cow's milk dadih during storage at room temperature and cold temperature of more than $10^{6} \mathrm{cfu} / \mathrm{ml}$ which could be categorized as a probiotic products. The combination of C1L5 (L.casei: B.longum 1: 5) has the lowest acidity value and excellence in character color, flavor, and was generally preferred by the panelists. In terms of flavor and texture characteristics of cow's milk dadih with a combination of C1L5 had a level of hedonic as with other formulas.
\end{abstract}

Keywords: dadih, cows milk, probiotic, storage

\section{PENDAHULUAN}

Dadih adalah golongan susu fermentasi seperti yoghurt dan kefir yang berasal dari Sumatera Barat. Dadih merupakan produk dari susu kerbau yang difermentasikan secara alami dalam wadah bambu pada suhu kamar selama 24-48 jam dengan dengan atau tanpa penutup daun pisang (Sirait, 1993; Sugitha,1995). Belum adanya standar pembuatan dadih menyebabkan kualitas dadih yang diperoleh berbeda-beda warna, aroma, dan rasa pada masing-masing pengolah. Pengolahan melalui proses fermentasi yang lebih terkendali dengan menggunakan starter bakteri asam laktat tanpa melibatkan bakteri patogen diharapkan dapat meningkatkan kualitas dadih yang dihasilkan.

Komposisi gizi dadih bervariasi yaitu kadar air $(82,10 \%)$, kadar protein $(6,99 \%)$, kadar lemak $(8,08 \%)$, keasaman $\left(130,5^{\circ} \mathrm{D}\right)$ dan
pH $(4,99)$. Secara umum komposisi dadih mempunyai kandungan lemak dan protein tinggi, dengan kadar protein rata-rata $6,75 \%$ (Yudoamijoyo et al., 1983). Namun produk dadih kurang dikenal secara luas di Indonesia karena adanya keterbatasan susu kerbau sebagai bahan baku pembuatan dadih yang mengakibatkan terbatasnya produksi dadih dan mahalnya harga dadih. Untuk itu perlu adanya subtitusi bahan baku dadih menggunakan susu sapi yang ketersediaannya retalif cukup berlimpah di beberapa wilayah Indonesia.

Pembuatan dadih dari susu sapi menggunakan starter L. casei yang termasuk golongan bakteri homofermentatif yang menghasilkan asam laktat pada proses metabolisme, belum bisa diterima karena rasanya yang masih terlalu asam dibandingkan dadih dari susu kerbau. Oleh karena itu salah satu cara untuk mereduksi rasa asam tersebut adalah dengan mengkombinasikan bakteri $L$. 
casei dengan bakteri lain yang menghasilkan citarasa keasaman yang relatif lebih rendah, misalnya dari golongan bakteri heterofermentatif seperti $L$. plantarum dan $B$. longum. Kombinasi starter ini selain meningkatkan cita rasanya, diharapkan dapat memberi nilai tambah terhadap dadih sebagai pangan fungsional (functional food) probiotik yang berguna bagi kesehatan.

Tujuan penelitian adalah untuk mengetahui karakteristik dadih probiotik menggunakan kombinasi starter $L$. casei, $L$. plantarum dan $B$. longum selama penyimpanan pada suhu ruang dan suhu dingin.

\section{MATERI DAN METODE}

\section{Bahan dan Alat}

Bahan utama yang digunakan adalah susu segar (Peternakan Darul Falah Bogor), skim (Kota Jaya $\left.{ }^{\circledR}\right)$, Carboxylmethyl Cellulose (CMC), starter Lactobacillus casei (hasil isolasi dari dadih susu kerbau Kabupaten Sijunjung, Sumatera Barat), Lactobacillus plantarum, dan Bifidobacterium longum (koleksi Balai Besar Penelitian dan Pengembangan Pascapanen). Bahan-bahan yang digunakan untuk analisis meliputi de Man Rogosa and Sharpe (MRS) agar (Pronadisa), MRS Broth (Pronadisa), akuades, bile salt (Oxoid), Sodium Sitrat (Sigma), Ribosa (Sigma), Lithium Klorida (Merck), Sodium Propionat (Sigma), $\mathrm{NaOH} 0,1 \mathrm{~N}, \mathrm{NaCl} 0,85 \%$, $\mathrm{HCl} 5 \mathrm{M}$ dan indikator Phenoptalen (PP). Jenis kemasan yang digunakan adalah cup plastik Polypropilen (PP) ukuran $50 \mathrm{ml}$ dan $120 \mathrm{ml}$.

Peralatan yang digunakann dalam penelitian ini meliputi panci stainless steel, termometer, $\mathrm{pH}$ meter (Eutech), lemari es, inkubator (Orbital), vortex (Scientific), autoclave (Hirayama), Quebec Colony Counter (Hellige), rheometer (Brookfield), timbangan analitik (Precisa), peralatan untuk pengujian organoleptik, kemasan cup plastik jenis polypropylene (pp), serta peralatan gelas untuk analisis.

\section{Metode}

Penelitian dilaksanakan dalam dua tahap yaitu penelitian pendahuluan dan penelitian utama. Tujuan penelitian pendahuluan adalah untuk: (i) mendapatkan waktu awal pertumbuhan eksponensial $L$. plantarum, L. casei, dan B. longum melalui pembuatan kurva pertumbuhan, (ii) waktu fermentasi dadih, (iii) persentase kultur kerja, serta (iv) perbandingan inokulum yang akan digunakan dalam penelitian utama. Sebelum penelitian utama dilakukan tahap-tahap kegiatan sebagai berikut :

(i) Aktivasi inokulum. Isolat BAL (L. casei, L. plantarum, dan B. longum) yang telah dibiakkan pada agar miring MRS diambil sebanyak 1 ose dan dimurnikan dengan metode goresan kuadran, kemudian diinkubasi pada suhu $37^{\circ} \mathrm{C}$ selama 48 jam. Biakan murni yang diperoleh dari metode kuadran ditumbuhkan pada $5 \mathrm{ml}$ MRSB steril dan diinkubasi pada suhu $37^{\circ} \mathrm{C}$ selama 24 jam. Pembuatan inokulum aktif dilakukan sebanyak dua kali untuk tiap isolat BAL.

(ii) Perbanyakan kultur BAL. Perbanyakan kultur dilakukan dengan menginokulasi sebanyak 30\% kultur aktif. Sebanyak $3 \mathrm{ml}$ kultur aktif BAL diinokulasikan secara aseptis pada $7 \mathrm{ml}$ media MRSB steril kemudian diinkubasi pada suhu $37^{\circ} \mathrm{C}$ selama 24 jam menjadi kultur induk.

(iii) Pembuatan kultur kerja BAL pada media susu. Kultur induk diinokulasikan sebanyak 3\% ke dalam MRSB steril menjadi kultur intermediate. Setelah diinokulasikan secara aseptis, diinkubasi pada suhu $37^{\circ} \mathrm{C}$ selama 24 jam. Kemudian $3 \%$ kultur intermediate diinokulasi ke dalam media susu steril dan diinkubasi selama waktu masing-masing BAL memulai fase eksponensial (logaritmik) pada suhu $37^{\circ} \mathrm{C}$.

(iv) Penggunaan persentase kultur kerja. Penggunaan persentase starter BAL dilakukan dengan membuat dadih sapi yang ditambah masing-masing starter tunggal BAL sebanyak $1 \%$ dan $3 \%$ ke dalam susu sapi yang telah diuapkan $50 \%$ (toning) serta ditambah $3 \%$ susu skim dan $0,1 \%$ CMC.

(v) Proses fermentasi. Fermentasi dilakukan dalam kemasan cup plastik sebanyak 50 $\mathrm{ml}$ dan difermentasi pada suhu ruang (27$30^{\circ} \mathrm{C}$ ). Pada jam ke-44, 46, dan 48 selama fermentasi (mengacu pada waktu pembuatan dadih tradisional selama 2 hari) dilakukan pengamatan fisik dan uji viskositas. Hal tersebut dilakukan untuk memperoleh persentase starter BAL dan waktu yang tepat untuk memanen dadih (tidak terjadi wheying off atau over fermentation). Pengamatan fisik dilakukan terhadap sensori warna, bentuk dan mouthfeel dadih. Penentuan waktu fermentasi dadih dilakukan dengan memilih lama fermentasi dadih selama 44 jam, 46 jam, dan 48 jam. Parameter 
pemilihan persentase starter dan penentuan waktu pemanenan dadih didasarkan pada viskositas dadih jam ke44, ke-46, dan ke-48.

(vi) Pembuatan kurva pertumbuhan. Parameter uji total BAL, pH dan TAT diuji dengan menginokulasi $3 \%$ kultur intermediate BAL ke dalam susu sapi steril. Ketiga parameter diamati mulai jam ke-0 yaitu saat awal kultur induk diinokulasi ke dalam susu sapi steril, selanjutnya disampling tiap jam selama 14 jam. Uji total BAL dilakukan untuk mengetahui pertumbuhan BAL tiap jam selama 14 jam. Pola pertumbuhan BAL dapat diketahui dari kurva pertumbuhan dengan memplotkan waktu fermentasi (jam) terhadap log jumlah BAL. Pembuatan kurva pertumbuhan bertujuan untuk mendapatkan waktu BAL sesaat akan melakukan pertumbuhan eksponensial. Waktu mulai pertumbuhan eksponensial merupakan waktu yang optimal untuk mencampur lebih dari 2 kultur dalam membuat dadih.

(vii) Penentuan perbandingan kombinasi starter. Penentuan perbandingan dilakukan dengan trial error dengan perbandingan $B$. longum atau $L$. plantarum lebih tinggi dibanding $L$. casei (dimulai dari perbandingan $L$. casei dengan BAL lainnya pada penelitian Suprihanto, 2009) yang menyatakan bahwa $L$. casei dan $B$. longum dengan perbandingan 1:2 masih mempunyai $\mathrm{pH}$ yang rendah dan TAT yang tinggi serta rasa yang masih asam, sehingga untuk mendapatkan rasa produk yang relatif tidak terlalu asam (sesuai minat masyarakat Sumbar atas rasa dadih susu kerbau) perlu ditambah BAL heterofermentatif agar produks metabolit tidak hanya asam, tetapi juga komponen flavor. Pengamatan dilakukan terhadap $\mathrm{pH}$ dan TAT serta preferensi terhadap rasa asam oleh panelis yang sering mengkonsumsi dadih.

\section{Penelitian Utama}

Penelitian utama merupakan aplikasi pembuatan produk menggunakan starter dengan persentase dan perbandingan terpilih pada penelitian pendahuluan. Bahan baku yang digunakan adalah susu sapi segar yang pasteurisasi dan diuapkan 50\% dari volume awal, yang ditambah $3 \%$ susu skim yang dihomogenkan dengan 0,01\% CMC. Starter BAL yang digunakan adalah BAL pada kondisi awal fase eksponensial hasil (dari pembuatan kurva pertumbuhan yaitu titik awal BAL mengalami pertumbuhan eksponensial). Starter kombinasi BAL untuk mengurangi rasa asam produk digunakan perbandingan yang terpilih dari kegiatan sebelumnya. Dadih sapi difermentasi dalam cup PP pada suhu ruang selama waktu hasil penelitian pendahuluan. Produk kemudian diamati pada suhu ruang $\left(27^{\circ} \mathrm{C}\right)$ selama 7 hari dan selama 21 hari pada suhu dingin $\left(4^{\circ} \mathrm{C}\right)$. Lama penyimpanan ditentukan berdasarkan hasil penelitian Suprihanto (2009).

Pengujian parameter meliputi $\mathrm{pH}$, TAT, viskositas, total BAL, jumlah koloni $L$. casei, B. longum, dan L. plantarum, serta uji probiotik (ketahanan BAL terhadap $\mathrm{pH}$ rendah dan garam empedu). Pengujian pada suhu ruang dilakukan pada hari ke-0, ke-4, dan ke7 , sedangkan pada suhu dingin pada hari ke-0, ke-14, dan ke-21. Uji organoleptik (hedonik) terhadap sensori rasa, aroma, warna, tekstur, dan penerimaan umum dilakukan terhadap 3 sampel dadih. Sebanyak 25 orang panelis semi terlatih melakukan penilaian kesukaan terhadap sampel berdasarkan skala hedonik: (1) tidak suka; (2) agak tidak suka, (3) biasa, (4) agak suka, dan (5) suka.

\section{Rancangan Percobaan}

Perlakuan dalam penelitian utama adalah jenis kombinasi starter (Faktor A) dan lama penyimpanan (Faktor B). Rancangan percobaan yang digunakan adalah Rancangan Acak Kelompok (RAK) faktorial 6x3 dengan tiga kali ulangan sebagai kelompok. Perlakuan A yaitu $L$. casei (A1), B. longum (A2), $L$. plantarum (A3), L. casei : L. plantarum 1:5 (A4), L. casei : B. longum 1:5 (A5) dan $L$. casei : L. plantarum:B. longum 1:4:1 dengan lama penyimpanan (B) yaitu : (B1) suhu ruang $\left(27^{\circ} \mathrm{C}\right)$, (B2) suhu dingin $\left(4-10^{\circ} \mathrm{C}\right)$. Data hasil penelitian dianalisis dengan ANOVA-Balanced ANOVA. Adanya perbedaan yang nyata $(p<0,05)$, dilanjutkan dengan uji Duncan dengan tingkat kepercayaan 95\% (Steel dan Torrie, 1993).

Model rancangan percobaan yang digunakan adalah sebagai berikut :

$$
\begin{aligned}
& Y_{i k}=\mu+R_{k}+A_{i}+B_{j}+A B_{i j}+\epsilon_{i j k} \\
& Y_{i k}=\text { Peubah respon karena pengaruh } \\
& \text { perlakuan kombinasi starter (A) } \\
& \mu \quad=\text { Pengaruh rata-rata }
\end{aligned}
$$




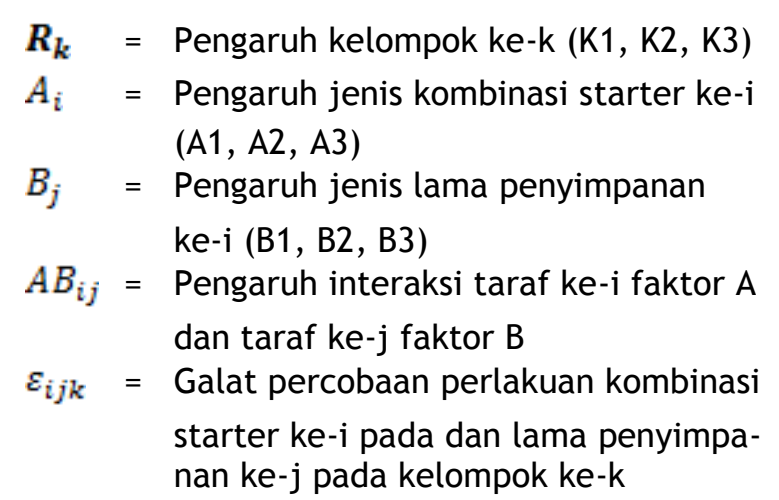

\section{HASIL DAN PEMBAHASAN}

\section{Penelitian Pendahuluan}

\section{a. Jumlah populasi starter BAL}

Menurut Overby (1988), jumlah populasi BAL untuk starter dalam pembuatan dadih susu sapi berkisar $5 \times 10^{8}-1 \times 10^{9} \mathrm{cfu} / \mathrm{ml}$. Hasil penelitian menunjukkan bahwa jumlah populasi bakteri pada kultur kerja berkisar $6,1 \times 10^{8}-1,1 \times 10^{9} \mathrm{cfu} / \mathrm{ml}$ (L.casei $1,1 \times 10^{9}$ $\mathrm{cfu} / \mathrm{ml}$, L. plantarum $8,2 \times 10^{8} \mathrm{cfu} / \mathrm{ml}, \quad B$. longum $\left.6,1 \times 10^{8} \mathrm{cfu} / \mathrm{ml}\right)$. Jumlah tersebut telah memenuhi syarat dalam pembuatan dadih susu sapi.

\section{b. Konsentrasi starter dan lama waktu pembuatan dadih}

Penggunaan konsentrasi starter 3\% memiliki nilai TAT yang sesuai dengan SNI berkisar 0,5-2\%. Nilai viskositas dadih jam ke44 hingga ke-48 menunjukkan kecenderungan yang terus meningkat, namun setelah lebih dari 48 jam terjadi sineresis karena terbentuknya metabolit sekunder proses fermentasi, sehingga untuk ketiga bakteri starter ditentukan bahwa lama fermentasi adalah 48 jam.

\section{c. Kurva pertumbuhan bakteri asam laktat}

Berdasarkan kurva pertumbuhan (Gambar 1) diketahui bahwa waktu awal fase pertumbuhan logaritmik/eksponensial, sehingga masing-masing bakteri starter mempunyai fase yang sama pada awal fermentasi. Pada jam ke-0, jumlah populasi masing-masing BAL berkisar $10^{7}-10^{8} \mathrm{cfu} / \mathrm{ml}$. Tiga sampai empat jam pertama inkubasi, ketiga BAL dalam keadaan adaptasi, setelah itu mulai fase logaritmik. Fase adaptasi L. plantarum dan $L$. casei adalah 4 jam, sedangkan $B$. longum selama 3 jam.

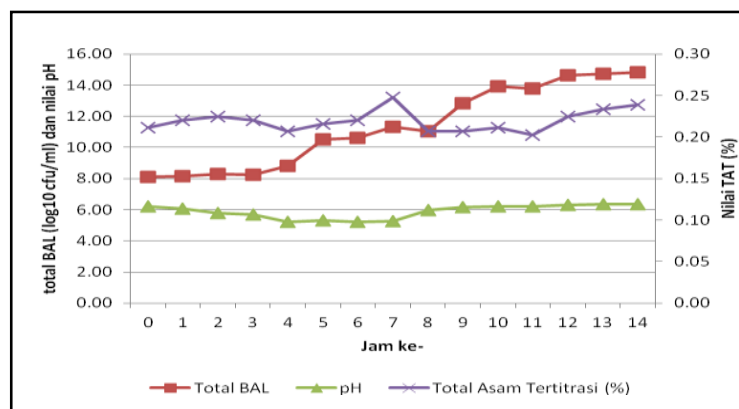

a. Kurva pertumbuhan L. plantarum

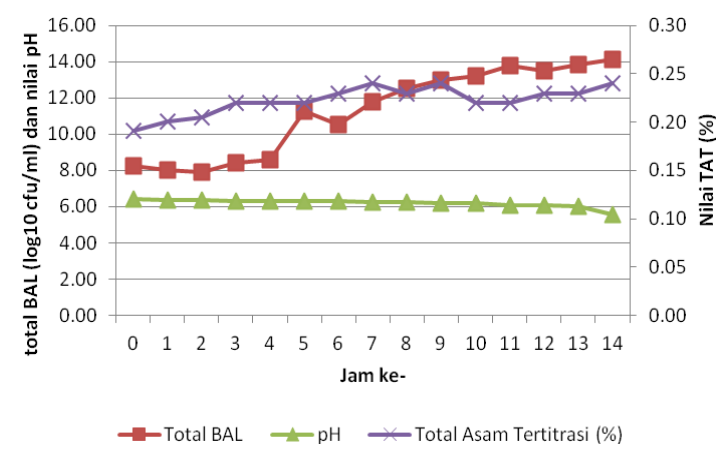

b. Kurva pertumbuhan L. casei

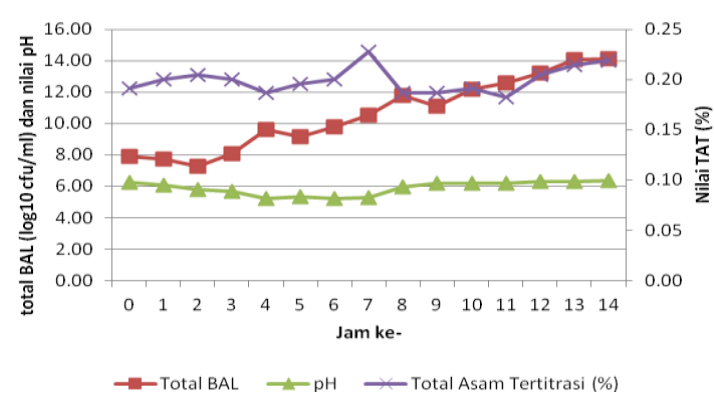

C. Kurva Pertumbuhan B. Longum

Gambar 1. Kurva Pertumbuhan Bakteri Asam Laktat yang Digunakan dalam Pembuatan Dadih

\section{d. Perbandingan Kombinasi Starter}

Lactobacillus plantarum dan B. longum merupakan BAL bersifat heterofermentatif yang dapat dikombinasikan dengan L. casei rasa asam pada dadih susu sapi dapat dikurangi. Kombinasi yang terpilih untuk pembuatan dadih adalah $L$. casei : $B$. longum (1:5), L. casei : L. plantarum (1: 5), dan $L$. casei : L. plantarum : B. longum (1:4:1). Kombinasi BAL ini memiliki tingkat keasaman yang cukup rendah dan secara organoleptik dapat diterima oleh panelis. 


\section{Penelitian utama}

Berdasarkan hasil penelitian pendahuluan, dadih susu sapi dibuat dengan menggunakan starter 3\%, lama fermentasi 48 jam pada kondisi suhu ruang $\left(27-30^{\circ} \mathrm{C}\right)$.

\section{Nilai pH}

Hasil analisis ragam menunjukkan bahwa formula starter BAL dan lama simpan di suhu ruang nyata $(p \leq 0,05)$ mempengaruhi nilai $\mathrm{pH}$, dan kedua faktor saling berinteraksi. Nilai $\mathrm{pH}$ dengan formula starter $L$. casei : $B$. longum 1:5 (C1L5) menunjukkan nilai $\mathrm{pH}$ tertinggi $(5,21)$.

Berdasarkan Gambar 2, nilai pH tertinggi $(5,21)$ dadih susu sapi pada suhu ruang diperoleh pada hari ke-0 dengan formula C1L5, sedangkan yang terendah $(3,33)$ diperoleh pada hari ke-7 dengan formula $L$. casei (LC). Keasaman dadih meningkat seiring lama simpan karena jumlah bakteri perombak laktosa semakin banyak sehingga asam laktat yang terbentuk maksimal dan menyebabkan rasa dadih menjadi asam. Menurut Sayuti (1993), banyaknya bakteri perombak laktosa dan lama fermentasi berengaruh terhadap tingkat keasaman dadih.

\begin{tabular}{|l} 
Keterangan : \\
: Dadih susu sapi menggunakan starter \\
L. casei
\end{tabular}

Gambar 2. Nilai pH dadih susu sapi pada suhu ruang $\left( \pm 27^{\circ} \mathrm{C}\right)$

Pada penyimpanan di suhu dingin, sidik ragam menunjukkan bahwa formula starter BAL dan lama simpan nyata $(P \leq 0,05)$ mempengaruhi nilai $\mathrm{pH}$, dan kedua faktor berinteraksi. Dadih dengan formula C1L5 memiliki nilai pH tertinggi $(5,21)$.

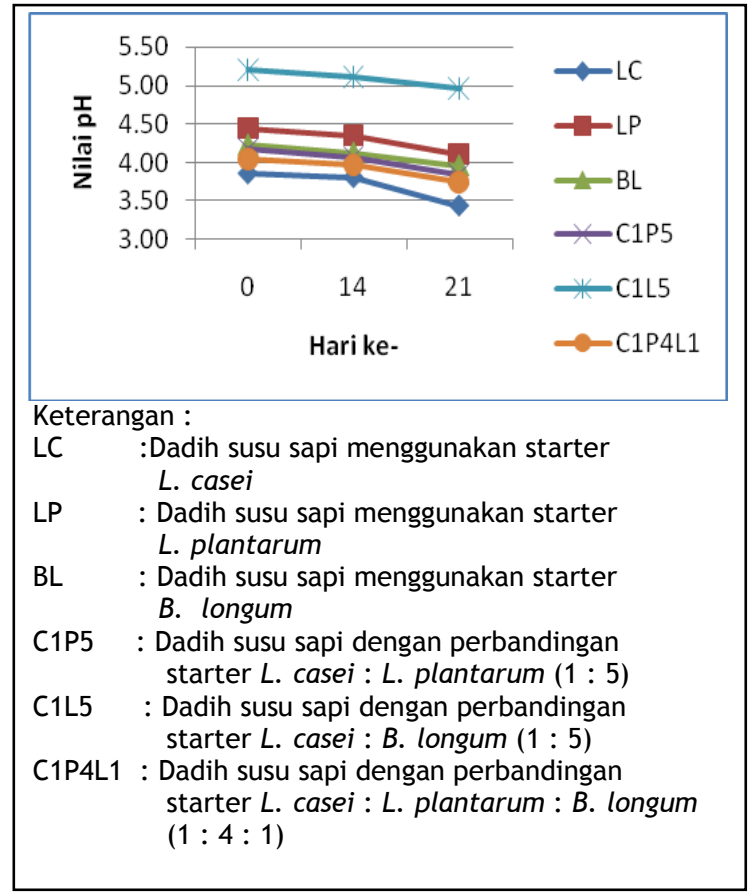

Gambar 3. Nilai pH dadih susu sapi pada suhu dingin $\left( \pm 4^{\circ} \mathrm{C}\right)$

Berdasarkan Gambar 3, nilai pH tertingg $(5,21)$ pada penyimpanan dadih susu sapi di suhu dingin diperoleh pada hari ke-0 dengan formula C1L5, sedangkan yang terendah $(3,44)$ diperoleh pada hari ke-21 dengan formula LC. Penurunan nilai $\mathrm{pH}$ dadih susu sapi pada penyimpanan di suhu ruang relatif lebih cepat karena suhu lingkungan (27$30^{\circ} \mathrm{C}$ ) masih mendukung aktivitas metabolisme dan pertumbuhan optimal bakteri. Menurut Widodo (2003), aktivitas BAL cenderung lebih cepat pada suhu ruang dibandingkan suhu rendah. Timbulnya asam laktat menyebabkan turunnya pH susu (Hadiwiyoto, 1994).

\section{Total Asam Tertitrasi}

Hasil analisis ragam menunjukkan bahwa lama simpan dan formula starter BAL pada penyimpanan di suhu ruang nyata $(P \leq 0,05)$ mempengaruhi nilai TAT, dan kedua fak̄tor saling berinteraksi. Nilai TAT dengan formula starter LC dan C1L5 berbeda dengan formula lainnya.

Berdasarkan Gambar 4, nilai TAT dadih susu sapi semakin meningkat selama penyimpanan 7 hari. Nilai TAT dadih susu sapi tertinggi $(1,25 \%)$ pada penyimpanan di suhu ruang diperoleh pada hari ke-7 menggunakan 


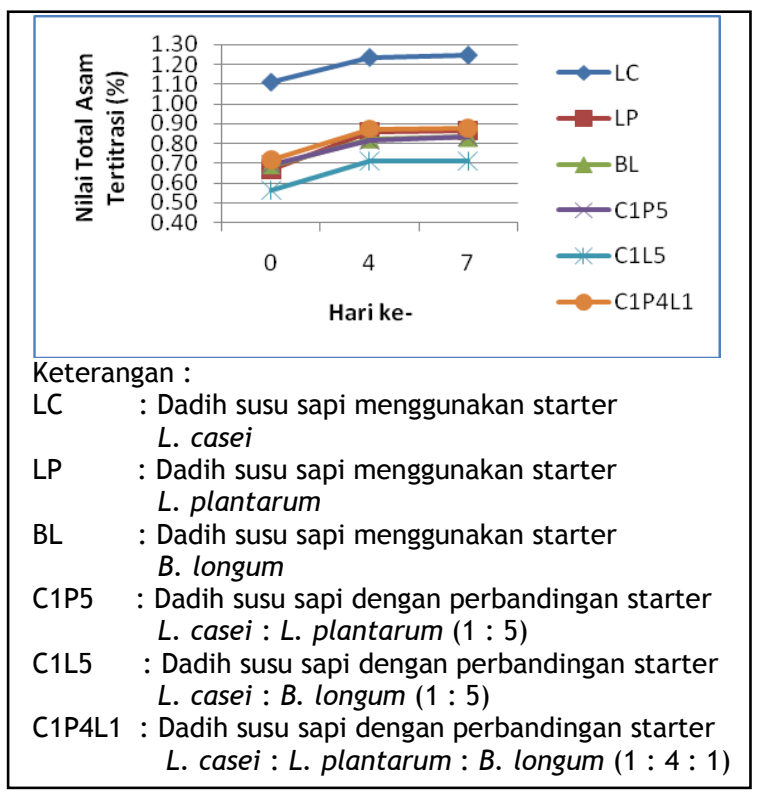

Gambar 4. Nilai TAT dadih susu sapi pada suhu ruang $\left( \pm 27^{\circ} \mathrm{C}\right)$

formula LC, sedangkan terendah $(0,52 \%)$ terdapat pada hari ke-0 dengan formula C1L5. Hasil nilai TAT berbanding terbalik dengan nilai pH. Produksi asam laktat oleh BAL menyebabkan keasaman dadih susu sapi meningkat selama penyimpanan yang ditunjukkan oleh rendahnya nilai $\mathrm{pH}$.

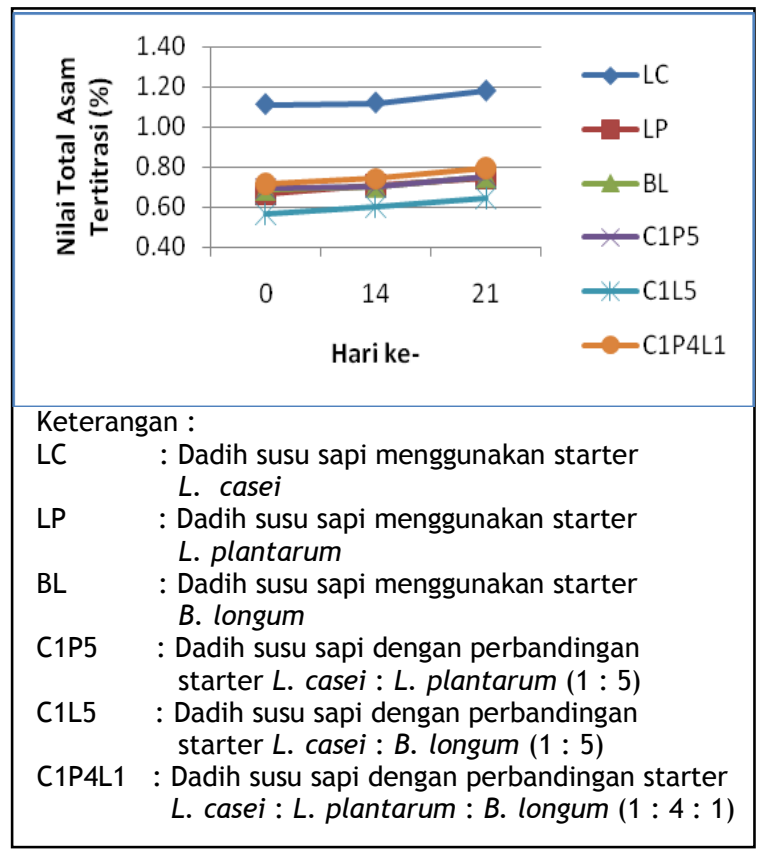

Gambar 5. Nilai TAT dadih susu sapi pada suhu dingin $\left( \pm 4^{\circ} \mathrm{C}\right)$

Pada penyimpanan di suhu dingin, sidik ragam menunjukkan bahwa formula starter BAL dan lama simpan nyata $(P \leq 0,05)$ mempengaruhi nilai TAT, dan kedua faktor tidak berinteraksi. Berdasarkan Gambar 5, nilai TAT dadih susu sapi makin meningkat selama penyimpanan. Nilai TAT dadih susu sapi terendah $(0,56 \%)$ pada penyimpanan di suhu dingin diperoleh pada hari ke-0 dengan formula starter C1L5, sedangkan nilai TAT tertinggi $(1,18 \%)$ diperoleh pada hari ke-21 dengan formula $L C$.

Aktivitas BAL tidak dihambat pada suhu ruang sehingga kenaikan produksi asam lebih cepat dibanding pada penyimpanan di suhu dingin. Suhu ruang $\left(27^{\circ} \mathrm{C}-30^{\circ} \mathrm{C}\right)$ merupakan suhu yang mendekati optimal untuk aktivitas dan pertumbuhan BAL yang rata-rata mempunyai suhu pertumbuhan optimal pada $37^{\circ} \mathrm{C}$ (Fardiaz, 1989). Pada suhu ruang aktivitas BAL cenderung lebih cepat dibandingkan pada suhu dingin (Widodo, 1993).

\section{Viskositas}

Hasil analisis ragam menunjukkan bahwa formula starter BAL dan lama simpan di suhu ruang nyata $(P \leq 0,05)$ mempengaruhi viskositas, dan kedua faktor saling berinteraksi. Viskositas dadih susu sapi dengan formula starter L. plantarum (LP) pada hari ke- 0 berbeda dengan formula lainnya.

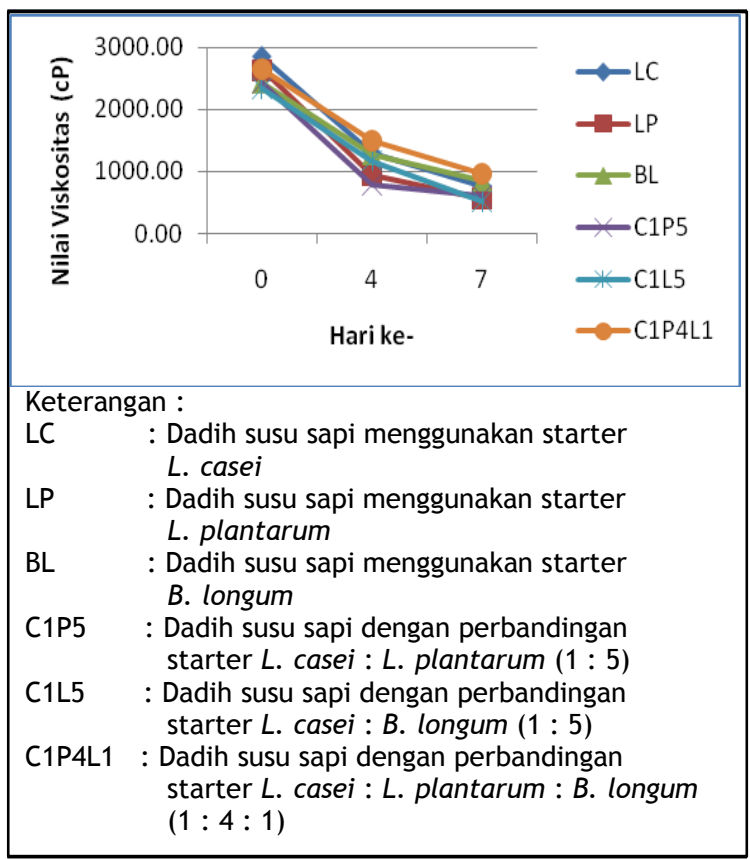

Gambar 6. Nilai Viskositas dadih susu sapi pada suhu ruang $\left( \pm 27^{\circ} \mathrm{C}\right)$

Berdasarkan Gambar 6, nilai viskositas dadih susu sapi terendah (523 cP) diperoleh pada penyimpanan di suhu ruang hari ke-7 dengan formula C1L5, sedangkan tertinggi 
(2855 cP) pada penyimpanan suhu ruang pada hari ke-0 dengan formula LC.

Pada penyimpanan di suhu dingin, hasil analisis ragam menunjukkan bahwa lama penyimpanan dan formula starter BAL berpengaruh nyata $(P \leq 0,05)$ terhadap nilai viskositas dadih susu sapi dan kedua faktor tersebut saling berinteraksi. Nilai viskositas dadih susu sapi dengan formula LC pada hari ke- 0 adalah tertinggi (2855 cP).

Keterangan :
: Dadih susu sapi menggunakan starter
LC casei

Gambar 7. Nilai Viskositas dadih susu sapi pada suhu dingin $\left( \pm 4^{\circ} \mathrm{C}\right)$

Berdasarkan Gambar 7, nilai viskositas dadih susu sapi terendah (1894 cP) pada penyimpanan di suhu dingin diperoleh dengan formula C1L5 pada hari ke-21, sedangkan tertinggi (2855 CP) diperoleh dengan formula LC pada hari ke-0. Penurunan viskositas disebabkan oleh lama simpan yang mengakibatkan berkurangnya penggunaan substrat untuk fermentasi, sehingga kemungkinan menyebabkan terbentuknya whey sebagai reaksi lanjut dari metabolit utama menjadi senyawa sekunder (Tamime and Robinson, 1999). Penurunan viskositas produk pada penyimpanan di suhu dingin tidak secepat di suhu ruang. Hal ini kemungkinan disebabkan aktivitas fermentasi oleh mikroba di suhu dingin tidak secepat di suhu ruang sehingga proses lanjut tersebut mungkin berjalan lebih lambat.

\section{Total bakteri asam laktat}

Total BAL dalam dadih susu sapi selama penyimpanan suhu ruang mempunyai nilai yang bervariasi (Gambar 8). Total BAL berkisar $3,2 \times 10^{9} \mathrm{cfu} / \mathrm{g}$ sampai $1,9 \times 10^{12} \mathrm{cfu} / \mathrm{g}$. Total BAL dadih susu sapi tertinggi mencapai $1,9 \times 10^{12} \mathrm{cfu} / \mathrm{g}$ terdapat pada dadih susu sapi dengan formula LC pada penyimpanan hari ke7, sedangkan terendah terdapat pada dadih susu sapi dengan formula BL pada penyimpanan hari ke-7 sebesar $3,2 \times 10^{9} \mathrm{cfu} / \mathrm{g}$.

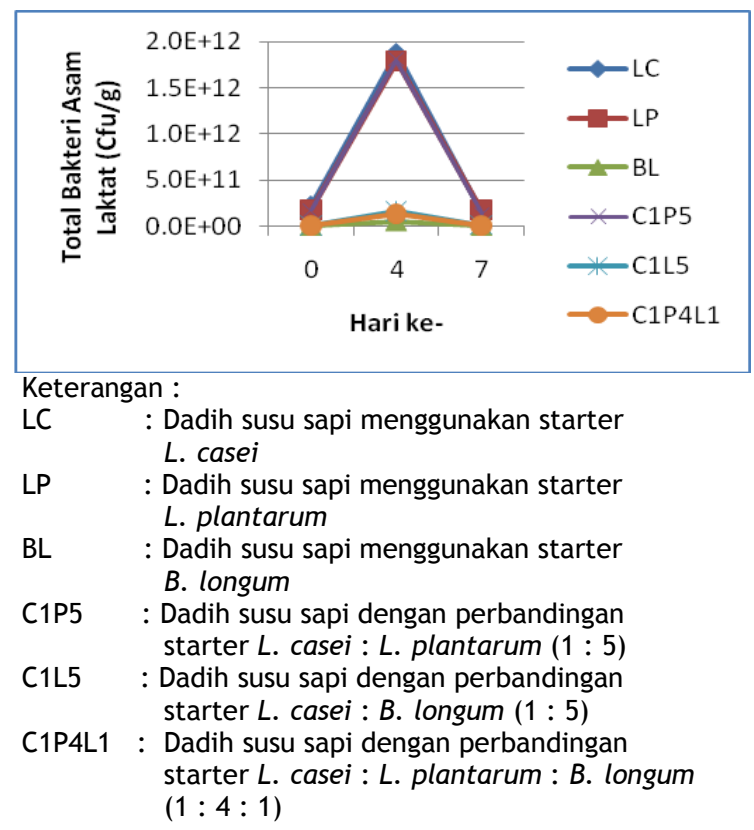

Gambar 8. Nilai Total BAL dadih susu sapi pada suhu ruang $\left( \pm 27^{\circ} \mathrm{C}\right)$

Berdasarkan Gambar 8, total BAL pada penyimpanan selama 0-4 hari mengalami kenaikan, namun pada hari ke-7 mulai menurun. Tampaknya sel bakteri mengalami lisis sehingga saat ditumbuhkan pada media MRSA jumlah yang dapat dihitung lebih sedikit seiring dengan lama simpan. Menurut Sunarlim dan Usmiati (2006), pada waktu tertentu jumlah substrat dalam bahan baku susu tersedia cukup banyak untuk difermentasi sehingga bakteri aktif memperbanyak diri. Semakin lama jumlah tersebut makin berkurang sehingga bakteri relatif tidak aktif memperbanyak diri dan bakteri sudah melewati fase logaritmiknya.

Pada penyimpanan di suhu dingin, hasil sidik ragam menunjukkan bahwa formula starter BAL nyata $(P \leq 0,05)$ mempengaruhi jumlah $B A L$, dan lama simpan dengan formula starter BAL saling berinteraksi. Total BAL dalam dadih susu sapi dengan starter LC pada hari ke-21 adalah tertinggi $\left(1,5 \times 10^{10} \mathrm{cfu} / \mathrm{g}\right)$. 


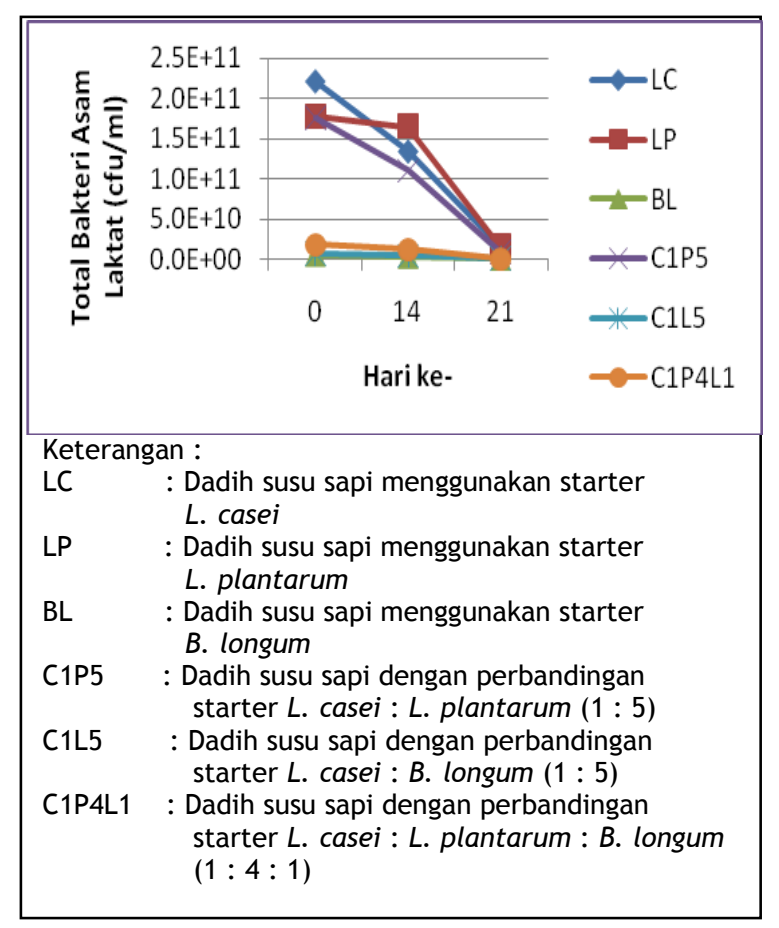

Gambar 9. Nilai Total BAL dadih susu sapi pada suhu dingin $\left( \pm 4^{\circ} \mathrm{C}\right)$

Berdasarkan Gambar 9, tampak bahwa total BAL dadih susu sapi menurun pada penyimpanan 21 hari. Hal ini kemungkinan disebabkan oleh aktivitas mikroba terhambat pada kondisi suhu rendah sehingga pertumbuhan BAL menjadi tidak optimal. Menurut Buckle et al. (2007), faktor utama yang mempengaruhi pertumbuhan mikroba antara lain suplai gizi, suhu, air, dan ketersediaan oksigen. Faktor lain adalah sel bakteri kemungkinan lisis akibat lingkungan yang makin asam seiring dengan lama simpan.

\section{Ketahanan bakteri asam laktat terhadap $\mathrm{pH}$ rendah}

Hasil analisis ragam menunjukkan bahwa lama simpan dan formula starter BAL pada penyimpanan di suhu ruang nyata $(P \leq 0,05)$ mempengaruhi ketahanan BAL terhadap $\mathrm{pH}$ rendah, dan kedua faktor saling berinteraksi. Formula starter C1L5 pada hari ke-0 menghasilkan ketahanan BAL terhadap $\mathrm{pH}$ rendah yang tertinggi $(1,56 \%)$.

Berdasarkan Gambar 10, ketahanan BAL terhadap pH rendah pada dadih susu sapi penyimpanan di suhu ruang tertinggi $(1,56 \%)$ diperoleh dengan formula C1L5 pada hari ke-0, sedangkan terendah $(0,53 \%)$ diperoleh dengan formula C1L5 pada hari ke-4. Total BAL terendah $\left(3,9 \times 10^{8} \mathrm{cfu} / \mathrm{g}\right)$ pada dadih yang disimpan di suhu ruang diperoleh dengan star-

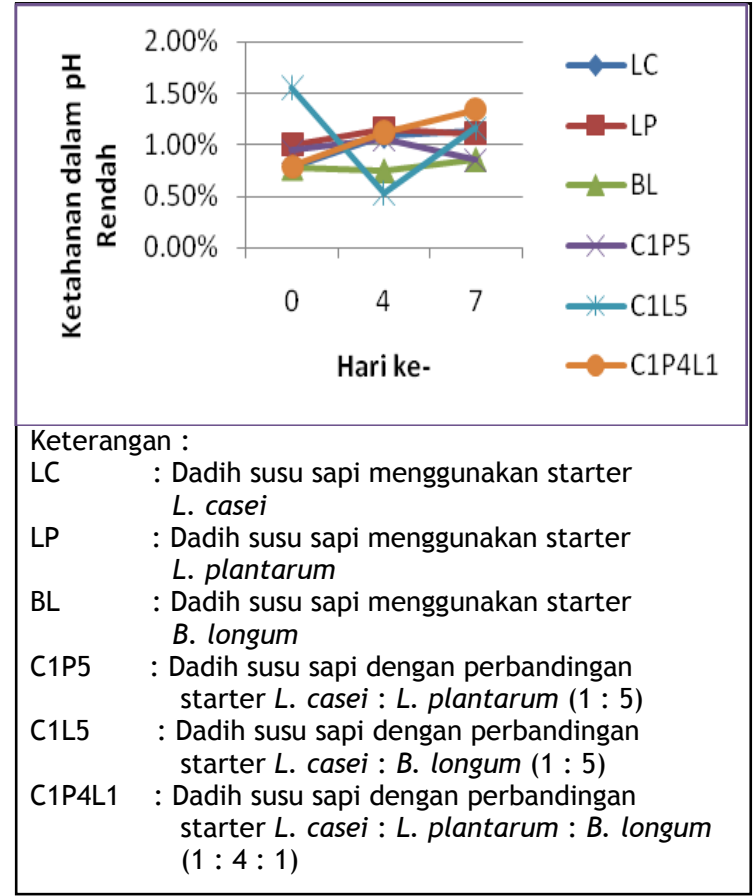

Gambar 10. Nilai ketahanan BAL terhadap pH rendah pada suhu ruang $\left( \pm 27^{\circ} \mathrm{C}\right)$

ter C1L5 pada hari ke-0, sedangkan total BAL tertinggi $\left(1,6 \times 10^{11} \mathrm{cfu} / \mathrm{g}\right)$ diperoleh dengan formula LC pada hari ke-4. Kisaran total BAL setelah ditumbuhkan dalam MRSB pH 3 adalah $3,1 \times 10^{6}$ hingga $1,8 \times 10^{9} \mathrm{cfu} / \mathrm{g}$. Total BAL terendah terdapat pada dadih susu sapi dengan formula starter $B$. longum (BL) pada penyimpanan hari ke-0, sedangkan tertinggi pada dadih susu sapi dengan formula LP pada penyimpanan hari ke-4.

Pada penyimpanan di suhu dingin, analisis ragam menunjukkan bahwa lama simpan dan formula starter BAL nyata $(P \leq 0,05)$ mempengaruhi nilai ketahanan BAL terhadap $\mathrm{pH}$ rendah, dan kedua faktor saling berinteraksi. Dadih susu sapi menggunakan formula starter LC pada penyimpanan hari ke21 dan BL pada penyimpanan hari ke-21 mempunyai nilai ketahanan terhadap $\mathrm{pH}$ rendah yang berbeda dibanding formula lainnya.

Berdasarkan Gambar 11, ketahanan BAL terhadap $\mathrm{pH}$ rendah pada penyimpanan suhu dingin dadih susu sapi yang tertinggi $(11,84 \%)$ diperoleh dengan formula LP pada penyimpanan hari ke-21, sedangkan yang terendah $(0,77 \%)$ diperoleh dengan formula $\mathrm{BL}$ pada penyimpanan hari ke-0. Total BAL terendah $\left(3,9 \times 10^{8} \mathrm{cfu} / \mathrm{g}\right)$ pada dadih susu sapi pada penyimpanan di suhu dingin diperoleh dengan formula C1L5 pada penyimpanan hari ke- 0 , sedangkan tertinggi $\left(1,7 \times 10^{10} \mathrm{cfu} / \mathrm{g}\right)$ 


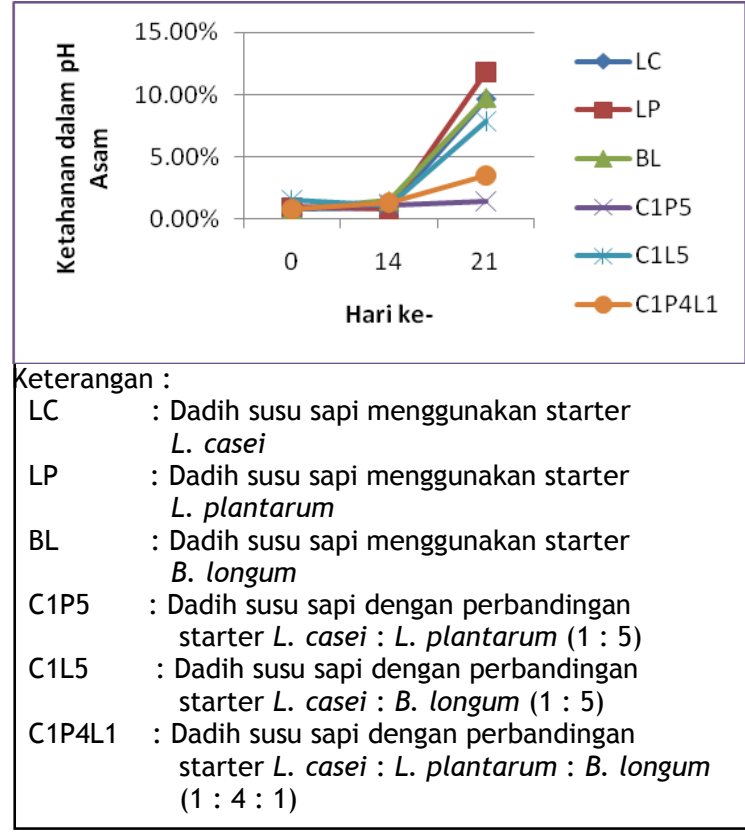

Gambar 11. Nilai Ketahanan BAL terhadap pH rendah pada suhu dingin $\left( \pm 4^{\circ} \mathrm{C}\right)$

diperoleh dari formula LP pada penyimpanan hari ke-14.Total BAL terendah setelah ditumbuhkan pada MRSB pH 3 didapatkan pada dadih susu sapi dengan formula starter BL pada penyimpanan hari ke-0, sedangkan tertinggi pada dadih susu sapi dengan formula starter LP pada penyimpanan hari ke-21.

Menurut Bouhnick yang dikutip oleh Chaterist et al. (1998) jumlah (viabilitas) mikroorganisme setelah melalui saluran pencernaan adalah sekitar $10^{6}-10^{7} \mathrm{cfu} / \mathrm{g}$, sedangkan jumlah minimal mikroorganisme probiotik dalam bioproduk untuk dapat memberikan manfaat kesehatan adalah minimal $10^{6} \mathrm{cfu} / \mathrm{g}$ produk. Berdasarkan hasil uji ketahanan BAL terhadap $\mathrm{pH}$ rendah, maka dadih susu sapi dalam penelitian ini telah memenuhi syarat produk probiotik. Beberapa penelitian menunjukkan bahwa BAL terutama Lactobacillus casei (Hardiningsih, 2006), L. plantarum (de Vries et al., 2006), dan B. longum (Zavaglia et al., 1998) dapat hidup pada keadaan $\mathrm{pH}$ rendah saluran pencernaan.

\section{Ketahanan bakteri asam laktat terhadap garam empedu}

Hasil analisis ragam menunjukkan bahwa lama simpan dan formula starter BAL pada penyimpanan di suhu ruang nyata $(P \leq 0,05)$ mempengaruhi nilai ketahanan $B A L$ terhadap garam empedu, dan kedua faktor saling berinteraksi. Berdasarkan Gambar 12, ketahanan BAL terhadap garam empedu dadih susu sapi pada penyimpanan di suhu ruang tertinggi $(13,01 \%)$ dengan formula C1P5 pada hari ke-0, sedangkan terendah $(0,56 \%)$ diperoleh dari formula BL hari ke-0.

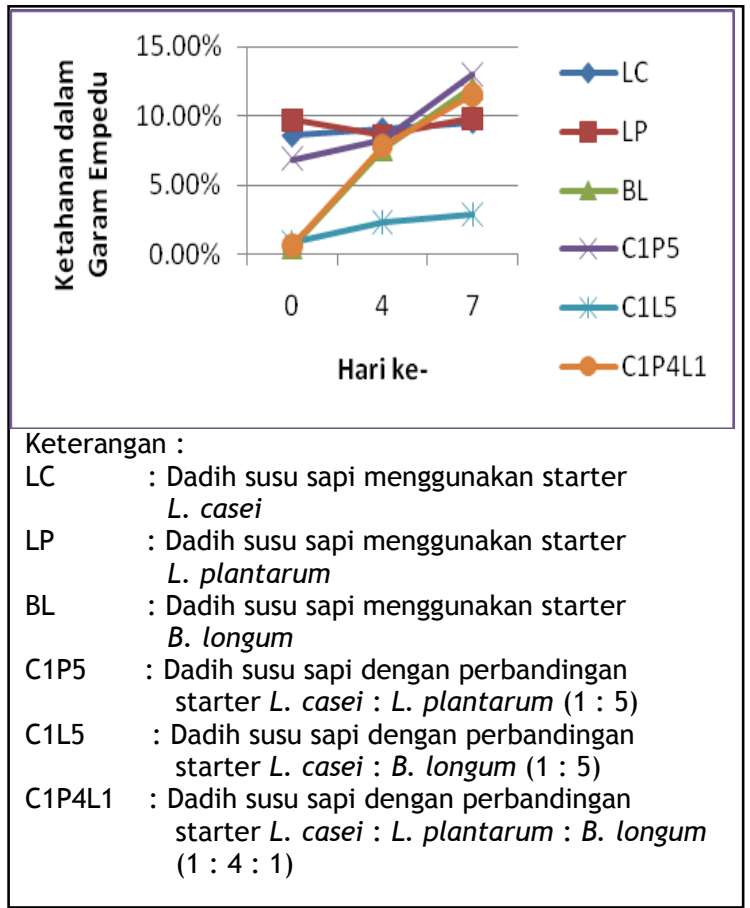

Gambar 12. Nilai ketahanan BAL terhadap garam empedu pada suhu ruang

Total BAL terendah $\left(3,2 \times 10^{9} \mathrm{cfu} / \mathrm{g}\right)$ pada dadih yang disimpan pada suhu ruang diperoleh dengan formula starter $\mathrm{BL}$ pada penyimpanan hari ke-7, sedangkan tertinggi $\left(1,9 \times 10^{12} \mathrm{cfu} / \mathrm{g}\right)$ diperoleh dengan formula LC pada penyimpanan hari ke-4. Kisaran total BAL setelah ditumbuhkan pada MRSA ditambah $0,3 \%$ garam empedu (bile salts) adalah $3,2 \times 10^{7}$ sampai $1,7 \times 10^{11} \mathrm{cfu} / \mathrm{g}$.

Pada penyimpanan di suhu dingin, hasil analisis ragam menunjukkan bahwa lama simpan dan formula starter BAL nyata $(P \leq 0,05)$ mempengaruhi nilai ketahanan BAL terhadap garam empedu, dan kedua faktor saling berinteraksi. Dadih susu sapi dengan starter LC pada penyimpanan hari ke-21 memiliki ketahanan terhadap garam empedu tertinggi $(49,51 \%)$.

Berdasarkan Gambar 13, ketahanan BAL terhadap garam empedu dadih susu sapi pada penyimpanan di suhu dingin tertinggi $(49,15 \%)$ diperoleh dengan formula starter LC pada hari ke-21, sedangkan terendah $(0,45 \%)$ diperoleh dari formula BL pada hari ke-14. Total BAL terendah $\left(3,1 \times 10^{8} \mathrm{cfu} / \mathrm{g}\right)$ pada dadih 


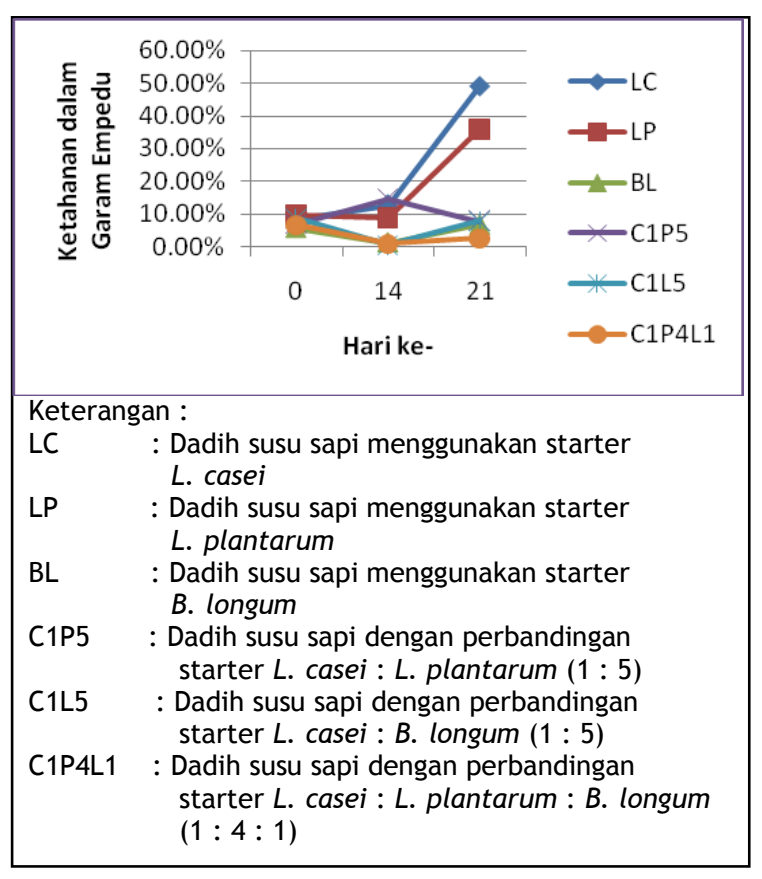

Gambar 13. Nilai Ketahanan BAL terhadap garam empedu pada suhu dingin

yang disimpan pada suhu dingin terdapat pada dadih dengan formula C1L5 pada penyimpanan hari ke-21, sedangkan tertinggi $\left(2,2 \times 10^{11}\right.$ $\mathrm{cfu} / \mathrm{g}$ ) diperoleh dengan formula LC pada penyimpanan hari ke-0. Total BAL terendah pada MRSA ditambah 0,3\% bile salts diperoleh pada dadih dengan formula BL pada penyimpanan hari ke-14, sedangkan tertinggi pada dadih susu sapi dengan formula LC pada penyimpanan hari ke-14.

Konsentrasi garam empedu $0,3 \%$ merupakan konsentrasi yang kritikal untuk menyeleksi isolat yang resisten terhadap garam empedu (Jacobson et al., 1999). Kisaran jumlah total BAL dadih susu sapi setelah ditumbuhkan pada media MRSA ditambah 0,3\% bile salts pada penelitian ini mempunyai jumlah yang cukup sebagai syarat produk probiotik menurut de Vries et al. (2006) yaitu $10^{6}-10^{8} \mathrm{cfu} / \mathrm{g}$.

\section{Uji Organoleptik}

Hasil uji hedonik terhadap warna, aroma, rasa, tekstur, dan penerimaan umum disajikan pada Tabel 1.

\section{a. Warna}

Hasil analisis ragam menunjukkan bahwa formula starter BAL berpengaruh nyata $(P \leq 0,05)$ terhadap tingkat kesukaan panelis terhadap warna dadih susu sapi. Dadih dengan starter C1L5 memiliki memiliki nilai kesukaan tertinggi $(4=$ suka $)$.

\section{b. Aroma}

Sidik ragam menunjukkan bahwa formula starter BAL tidak mempengaruhi tingkat kesukaan panelis terhadap aroma dadih susu sapi. Nilai tingkat kesukaan panelis terhadap aroma dadih susu sapi pada semua formula starter adalah 3 (biasa).

\section{c. Rasa}

Berdasarkan analisis ragam, formula starter BAL nyata $(P \leq 0,05)$ mempengaruhi tingkat kesukaan panelis terhadap rasa dadih susu sapi. Dadih dengan formula starter C1L5 memiliki nilai kesukaan tertinggi ( 4 = suka).

\section{d. Tekstur}

Analisis ragam menunjukkan bahwa formula starter BAL tidak mempengaruhi tingkat kesukaan panelis terhadap tekstur dadih susu sapi. Tingkat kesukaan panelis terhadap tekstur dadih susu sapi pada semua formula starter adalah 3 (biasa).

\section{e. Penerimaan umum}

Berdasarkan analisis ragam, formula starter nyata $(P \leq 0,05)$ mempengaruhi tingkat kesukaan panelis terhadap penerimaan umum dadih susu sapi. Dadih susu sapi dengan formula starter BAL C1L5 memiliki tingkat kesukaan tertinggi $(4=$ suka $)$.

Tabel 1. Nilai modus organoleptik dadih susu sapi probiotik

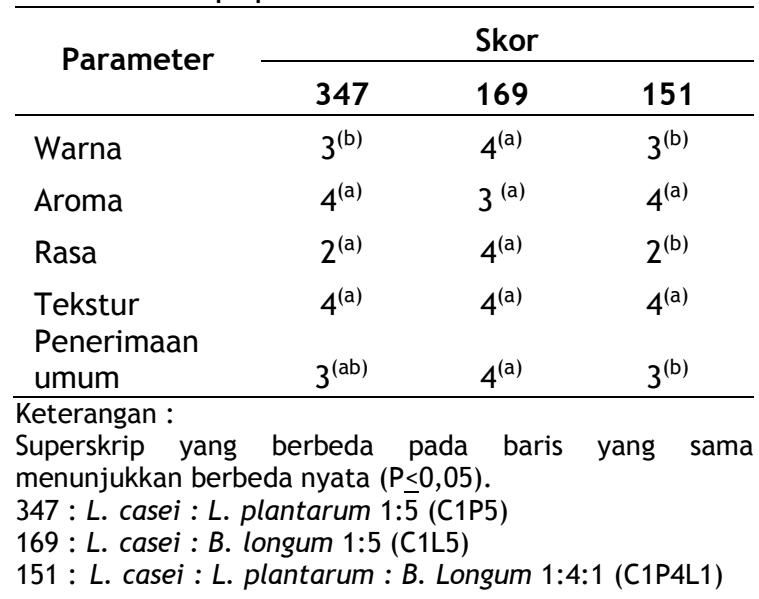

\section{KESIMPULAN}

Viabilitas bakteri asam laktat dalam dadih susu sapi yang disimpan pada suhu ruang dan suhu dingin dapat dipertahankan lebih dari $1 \times 10^{6} \mathrm{cfu} / \mathrm{g}$ pada uji ketahanan terhadap $\mathrm{pH}$ asam dan garam empedu, sehingga telah 
memenuhi syarat sebagai produk probiotik. Dadih susu sapi dengan starter $L$. casei : $B$. longum 1:5 (C1L5) memiliki rasa asam yang relatif rendah dengan keunggulan pada karakter warna, rasa, yang secara umum diminati oleh panelis.

\section{UCAPAN TERIMA KASIH}

Penulis menyampaikan terima kaasih kepada Budi Setiawan, STP (alumnus Fakultas Teknologi Pertanian, Departemen Teknologi Industri Pertanian, Institut Pertanian Bogor) atas bantuannya dalam pelaksanaan penelitian ini, serta dan Drs. Purwoko, Msi (Dosen pada Fakultas Teknologi Pertanian, Departemen Teknologi Industri Pertanian, Institut Pertanian Bogor) atas segala bimbingannya.

\section{DAFTAR PUSTAKA}

Buckle KA, Edwards RA, Fleet GH, \& Wotton M. 2007. Ilmu Pangan. Terjemahan Purnomo dan Adiono. Ul-Press. Jakarta.

Charteris WP, Kelly PM, Morelli L, \& Collins J.K. 1998. Development and application of in-vitro methodology to determine the transit tolerance of potentially probiotic Lactobacillus and Bifidobacterium species in the upper human gastrointestinal tract. Journal of Applied Bacterioogy., 84: 759-768.

De Vries MC, Vaughan EE, Michiel Kleerebezem, \& Willem M. de Vos. 2006. Lactobacillus plantarumsurvival, functional and potential probiotic properties in human intestinal tract. International Dairy Journal 16: 1018-1028.

Fardiaz S. 1989. Penuntun Praktek Mikrobiologi Pangan. Institut Pertanian Bogor, Bogor.

Hadiwiyoto S. 1994. Teknik Uji Mutu Susu dan Hasil Olahannya. Edisi kedua. Liberty, Yogyakarta

Hardiningsih R, Napitupulu RNF, \& Yulinery T. 2005. Isolasi dan Uji Resistensi Beberapa Isolat Lactobacillus pada $\mathrm{pH}$ Rendah. Biodiversitas Vol. 7 No. 1: 1517.
Jacobson CN, Nielsen VR, Hayford AE, Moller $\mathrm{PL}$, Michaelsen KF, Erregaard AP, Sandstrom B, Tvede $M \&$ Jakobsen $M$. 1999. Screening of probiotic activities of forty seven strains of Lactobacillus spp. by in vitro techniques and evaluation of the colonization ability of five selected strains in human. Applied And Environmental Microbiology. 65: 4949-4956

Overby AJ. 1988. Microbial Culture for Milk Processing. In: Meat Science, Milk Science and Technology. Elsevier Science Publisher B. V. New York.

Sayuti K. 1993. Mempelajari Mutu Dadih pada Lama Penyimpanan dan Jenis Bambu yang Berbeda. Skripsi. Fakultas Pertanian. UNAND. Padang.

Sirait CH. 1993. Pengolahan Susu Tradisional untuk Perkembangan Agroindustri Persusuan di Pedesaan. Laporan Hasil Penelitian. Balai Penelitian Ternak. Ciawi, Bogor.

Steel RGD \& Torrie JH. 1993. Prinsip dan Prosedur Statistika. Cetakan ketiga. PT Gramedia. Jakarta.

Sugitha IM. 1995. Dadih Makanan Tradisional Minang: Manfaat dan Khasiatnya. Dalam Widyakarya Nasional Khasiat Makanan Tradisional. Kantor Menteri Negara Urusan Pangan RI, Jakarta. Hal 532 - 540.

Sunarlim R, \& Usmiati S. 2006. Sifat Morfologi dan Sensori Dadih Susu Sapi yang di Fermentasi Menggunakan Lcatobacillus plantarum dalam Kemasan yang Berbeda. Buletin Peternakan. Vol. 30 (4).

Suprihanto AJ. 2009. Pengaruh Jenis BAL Terhadap Kualitas Dadih Susu Probiotik Selama Penyimpanan. Skripsi. Fakultas Teknologi Pertanian, Institut Pertanian Bogor. Bogor.

Tamime AY \& Robinson RK. 1999. Yoghurt Science and Technology. CRC Press., Washington DC.

Widodo. 2003. Bioteknologi Industri Susu. Cetakan Pertama. Lacticia Press, Yogyakarta. 
Yudoamijoyo RM, Zoelfikar T, Herastuti SR, Tomomatsu A, Matsuyama A \& Hosono A. 1983. Chemical and microbiological aspect of dadih in Indonesia. Japanese J. of Dairy and Food Science, 32 (1), 1 10.
Zavaglia AG, Kociubinski G, Perez P, \& De Antoni G. 1998. Isolation and characterization of Bifidobacterium strains for probiotic formulation. Journal Food Protect. 61(7): 865-873 